\title{
UTILIZATION OF CATECHINS IN SUNSCREEN LOTION FORIMULATION
}

\author{
"Sefrianita Kamal \& Mesa Sukmadani Rusdi \\ Department of Pharmacy, Dharma Andalas University, Padang, Indonesia \\ *e-mail: seprianita.k@unidha.ac.id
}

\begin{abstract}
Skin is the outermost part of body which is susceptible to sun radiation. Excessive radiation from ultraviolet (UV) rays can harm the skin, such as premature aging effect, erythema, and even skin cancer. Antioxidant compounds are needed to protect the skin from excessive exposure of UV rays. Antioxidant can be useful as defense system against free radicals, ultraviolet radiation, and air pollution. One source of antioxidant from nature is Catechins. Catechins are obtained from isolation of gambir (Uncaria gambir Roxb). Besides being useful as an antioxidant, Catechins also have antibacterial, antiseptic and wound healing effect. The antioxidant activity of Catechins can absorb UV rays, provides protection against oxidative stress, inflammation and skin cancer. Therefore, the research is necessary to utilize the catechins in sunscreen lotion formulation. Catechins are isolated from gambir by maceration with hexane and ethyl acetate (polar, nonpolar and residual fractions). The fraction which yields the most catechins is used as the active substance in the formulation. The formulation is divided into 4 lotion formulas, namely Formula I with $0.5 \%$ catechins concentration, Formula 2 with 7.5\% catechins concentration, Formula 3 with $1 \%$ catechins concentration, and Formula 4 without catechins substance. Physical stability test and effectiveness of sunscreen formulation are carried out on 4 lotion formulas. Physical stability tests, included organoleptic observation, homogeneity, $\mathrm{pH}$, and assessment of the effectiveness of sunscreen formulation by using UV-Vis Spectrophotometer.
\end{abstract}

Keywords: Catechins, Gambir, Uncaria gambir Roxb, Lotion, Sunscreen

\section{INTRODUCTION}

The skin is the outermost part of the human body that serves as a protective barrier from the body's internal organs and the environment. Skin aging is irreversible usually begins at age 20 , even though the sign - external signs have not seen in a long time. Skin aging is a biological process that is a complex of intrinsic factor (derived from the body, changes with time) and extrinsic factors caused by the environment (such as exposure to ultraviolet light, the repetition of facial expressions, gravity, sleeping positions, and smoking) (Mackiewicz \& Rimkevicius, 2008).

The skin has a complex protective mechanism against harmful environmental and chemical compounds. But exposure continues - going and excess can damage the protection systems that result in oxidative stress, DNA damage, cell damage, suppression of the immune system, inflammation and premature aging of the skin. The theory of free radical or oxidative stress theory is the theory most widely attributed to the aging process. Oxidative stress is a term that describes the imbalance between the number of free radicals and the body's antioxidant defenses (Lobo et al., 2010). Free radicals are atoms or molecules are reactive with an unpaired electron. Radical UV is a potential trigger the formation of free radical's ROS (Reactive Oxygen Species) on the skin.

Compounds that can counteract free radicals are antioxidants. Antioxidants are molecules that provide a stable enough electrons to reduce the activity of free radicals and neutralizing them so as to slow down or inhibit further cell damage. Antioxidants act as free radical neutralizers through two mechanisms, namely the provision of an electron to the free radicals present in the system and the removal of the initial compounds of ROS (Lobo et al., 2010). Alongside antioxidants that are presented in the body, antioxidants can also be obtained from nature. One of the natural antioxidant is catechins form gambir (Uncaria gambir Roxb).

Gambir is a plant that grows in tropical regions, such as in Indonesia and is usually used as an antidiarrheal and astringent. Most gambir in Indonesia from West Sumatra (90\%), South Sumatra and Bengkulu. The content of the extract gambir is approximately $7-33 \%$ catechins, tannins catechu acid 20-55\%, 20-30\% pyrocatechol, gambier fluorescent $\mathrm{I}-3 \%, 3-5 \%$ red catechu, quercetin $2-4 \%$, fixed oil I-2\% and wax I-2\% (Isnawati et al., 20I2).

Gambir extract containing polyphenols class of compounds, namely catechins. Catechin tannins is a class of compounds oligomeric procyanidin (OPC) which is a pharmacologically, such as flavonoids and are often classified as flavonoids (Isnawati et al., 2012). Flavonoids are known to have antioxidant properties. In a previous study, the activity of catechins as an antioxidant and antibacterial has been used as a medicine antiaging, antiacne, skin care, anti-free radical supplement drinks (Towaha, 2010). Phenolic compounds in particular flavonoid and tannin have the potential for their sunscreen chromophore group (single-conjugated double bonds) which can absorb UV rays 
both UV-A and UV-B (Sa'adah, 2010; Shovyana \& Zulkarnain, 20I3).

Catechins have antioxidant activity which can be used as a sunscreen and prevent premature aging of the skin. To use easier and more enjoyable then be made to a cosmetic product and anti-aging sunscreen with a high content of natural antioxidants. These antioxidants may be formulated in the form of cosmetic preparation, either in the form of cream, gel or lotion (Winarsi, 2007).

Lotion cosmetic preparation cosmetic preparation is a result of oil in water emulsion (oil in water or O/W) is used to make the skin smooth, moist, fresh and radiant. Lotions in the market is dominated by the stocks of chemical raw material / synthetic and not natural. The use of synthetic lotion has many advantages, such as easy to come by and many choices. However, synthetic lotion also has some disadvantages, such as it can cause irritation with burning, stinging, and contact allergy. Sunscreen of metal oxides although not cause dermal reactions, but less acceptable because it can form a barrier film layer on the skin and can cause an uncomfortable feeling (Purwaningsih et al., 2015). Therefore, the tendency of returning to nature also causes an increase in public demand for safe cosmetics and natural material with a high content of antioxidants. It can provide opportunities for research sunscreen lotion formulation of the use of catechins isolated from gambir.

\section{MATERIAL AND METHODS}

\section{Tools and Materials}

The equipment used includes UV-Vis spectrophotometer, $\mathrm{pH}$ meter, maceration chamber, and oven. The materials used in this study were gambir, cera alba, tween 80 , cetyl alcohol, stearyl alcohol, liquid paraffin, methyl paraben, propyl paraben, and distilled water.

\section{Methods}

Gambir used came from South Coastal Surantih. Isolated by recrystallization techniques. The formulation of each lotion was shown in table I.

Table I. Formula of catechins lotion

\begin{tabular}{|c|c|c|c|c|c|}
\hline \multirow{2}{*}{ Material } & \multicolumn{4}{|c|}{ Formula (\%) } & \multirow{2}{*}{ Function } \\
\hline & $\mathrm{FI}$ & $\mathrm{F} 2$ & F3 & $\mathrm{F} 4$ & \\
\hline Catechin & 0.5 & 0.75 & 1 & - & $\begin{array}{c}\text { Active } \\
\text { substance }\end{array}$ \\
\hline Cera alba & 7 & 7 & 7 & 7 & $\begin{array}{l}\text { Emulsion } \\
\text { stabilizer }\end{array}$ \\
\hline Tween 80 & 7 & 7 & 7 & 7 & Emulsifier \\
\hline $\begin{array}{c}\text { Cetyl } \\
\text { alcohol }\end{array}$ & 3 & 3 & 3 & 3 & $\begin{array}{l}\text { Emulsifier, } \\
\text { emolients }\end{array}$ \\
\hline $\begin{array}{l}\text { Stearyl } \\
\text { alcohol }\end{array}$ & 2 & 2 & 2 & 2 & $\begin{array}{l}\text { Emulsifier, } \\
\text { emolients }\end{array}$ \\
\hline
\end{tabular}

\begin{tabular}{|c|c|c|c|c|c|}
\hline $\begin{array}{c}\text { Liquid } \\
\text { paraffin }\end{array}$ & 10 & 10 & 10 & 10 & Softening \\
\hline $\begin{array}{c}\text { Methyl } \\
\text { paraben }\end{array}$ & 0.18 & 0.18 & 0.18 & 0.18 & Preservative \\
\hline $\begin{array}{l}\text { Propyl } \\
\text { paraben }\end{array}$ & 0.02 & 0.02 & 0.02 & 0.02 & Preservative \\
\hline Ottar & 3 drops & 3 drops & 3 drops & 3 drops & Deodorizer \\
\hline $\begin{array}{l}\text { Distilled } \\
\text { water ad }\end{array}$ & 100 & 100 & 100 & 100 & Solvent \\
\hline
\end{tabular}

After each lotion formula is made, an accelerated stability test with cycling test for each formula is carried out. Cycling test done by storing the preparation lotion at $5 \pm$ $2{ }^{\circ} \mathrm{C}$ for 24 hours, then transferred to an oven at $40 \pm 2$ ${ }^{\circ} \mathrm{C}$ for 24 hours. This treatment is counted one cycle and performed a total of 6 cycles ( 12 days). Furthermore, the observation of the organoleptic, homogeneity, $\mathrm{pH}$, dispersive, adhesiveness and viscosity.

Organoleptic inspection include form, color, and smell were observed directly. Homogeneity examination done by putting $50 \mathrm{mg}$ of lotion to the clean glass and observed using optical microscope at a magnification of 10 times (Aghel et al., 2007). $\mathrm{PH}$ probe begins with $\mathrm{pH}$ meter calibration using buffer solution $\mathrm{pH} 4$ and 7. The $\mathrm{pH}$ measurement is done by dipping $\mathrm{pH}$ meter. Measurements were made every period of time for 30 days.

Lotion samples are divided in various concentrations, namely $0.5 \%, 0.75 \%, 1 \%$, and lotion form without active ingredient of 0.5 gram dissolved in $25 \mathrm{~mL}$ ethanol $90 \%$ (20,000 ppm). Absorbance of each sample solution was measured by UV-Vis spectrophotometer. Absorbance spectrum obtained in the range of $290-320 \mathrm{~nm}$, at every interval of $5 \mathrm{~nm}$. SPF value is determined using equation ( 1 ) (Mansour et al., 1986; Sayre et al., 1979).

$$
S P F=C F \sum_{290}^{320} E E(\lambda) \times 1(\lambda) \times A(\lambda) \ldots(1)
$$

\section{RESULTS AND DISCUSSION}

Catechin obtained by maceration of gambir using ethyl acetate solvent, and recrystallization using $\mathrm{N}-\mathrm{H}$ exane, obtained yield of $81 \%$. By using a HPLC purity level of $95 \%$. The purity test was conducted with melting point of catechins were at a temperature of $176-177^{\circ} \mathrm{C}$ (Catechin purity limit $175-180^{\circ} \mathrm{C}$ ). The results of organoleptic evaluation were shown in table 2 .

Table 2. Evaluation of organoleptic parameter from lotion

\begin{tabular}{|c|c|c|c|c|}
\hline \multirow{2}{*}{ Parameter } & \multicolumn{4}{|c|}{ Evaluation } \\
\hline & $\mathrm{FI}$ & F2 & F3 & F4 \\
\hline Organoleptic & & & & \\
\hline $\begin{array}{l}\text { - Form } \\
\text { - Color } \\
\text { - Smell }\end{array}$ & $\begin{array}{l}\text { Semisolid } \\
\text { White } \\
\text { Aq rosae }\end{array}$ & $\begin{array}{l}\text { Semisolid } \\
\text { White } \\
\text { Aq rosae }\end{array}$ & $\begin{array}{l}\text { Semisolid } \\
\text { White } \\
\text { Aq rosae }\end{array}$ & $\begin{array}{l}\text { Semisolid } \\
\text { White } \\
\text { Aq rosae }\end{array}$ \\
\hline
\end{tabular}




\begin{tabular}{ccccc}
\hline Centrifuging & Stable & Stable & Stable & Stable \\
Freezer & Stable & Stable & Stable & Stable \\
Oven & Stable & Stable & Stable & Stable \\
\hline
\end{tabular}

Catechin sunscreen lotion preparations stable enough for storing 2 months in the treatment of $37-40^{\circ} \mathrm{C}$. While the treatment of accelerated stability test with one cycle of temperature a temperature of $5 \pm 2{ }^{\circ} \mathrm{C}$ for 24 hours and then proceed to the oven at a temperature of $40 \pm 2{ }^{\circ} \mathrm{C}$ for 24 hours. Shows separation and discoloration on the $6^{\text {th }}$ cycle/day $\mathrm{II}^{\text {th }}$ and $12^{\text {th }}$. Measurement of $\mathrm{pH}$ to sample with and without cycling test was shown in table 3 and 4. Measurement of $\mathrm{pH}$ on sunscreen lotion using a $\mathrm{pH}$ meter obtained average bases (According to skin $\mathrm{pH} 6$ - 8).

Table 3. Measurement of $\mathrm{pH}$ sample with cycling test

\begin{tabular}{cccccccccc}
\hline & \multicolumn{8}{c}{$\mathrm{PH}$} \\
\cline { 2 - 9 } Formula & \multicolumn{2}{c}{$\mathrm{FI}$} & \multicolumn{2}{c}{$\mathrm{F} 2$} & \multicolumn{2}{c}{$\mathrm{F} 3$} & \multicolumn{2}{c}{$\mathrm{F} 4$} \\
\cline { 2 - 9 } & 4 & 7 & 4 & 7 & 4 & 7 & 4 & 7 \\
\hline $\mathrm{I}$ & 4.2 & 7.2 & 5.7 & 6.5 & 5.3 & 6.9 & 6 & 7.2 \\
2 & 4.3 & 7 & 5.5 & 7.1 & 5.3 & 6.7 & 5.9 & 7.2 \\
3 & 4.4 & 6.8 & 5.3 & 6.8 & 5.2 & 7 & 5.7 & 7.3 \\
4 & 4.4 & 6.9 & 5 & 6.9 & 5.5 & 7 & 5.9 & 7.4 \\
\hline
\end{tabular}

Table 4. Measurement of $\mathrm{pH}$ sample without cycling test

\begin{tabular}{|c|c|c|c|c|c|c|c|c|}
\hline \multirow{3}{*}{ Formula } & \multicolumn{8}{|c|}{$\mathrm{pH}$} \\
\hline & \multicolumn{2}{|c|}{$\mathrm{FI}$} & \multicolumn{2}{|c|}{ F2 } & \multicolumn{2}{|c|}{ F3 } & \multicolumn{2}{|c|}{$\mathrm{F} 4$} \\
\hline & 4 & 7 & 4 & 7 & 4 & 7 & 4 & 7 \\
\hline I & 5.2 & 6.9 & 5.4 & 7.2 & 6.1 & 7.3 & 5.6 & 7 \\
\hline 2 & 5.4 & 7 & 5.2 & 7.2 & 5.4 & 7.1 & 5.6 & 7.1 \\
\hline 3 & 5.6 & 7 & 5 & 7.2 & 5.5 & 7.1 & 5.8 & 7.2 \\
\hline 4 & 5.5 & 7 & 4.7 & 7.3 & 5.4 & 7.1 & 5.5 & 7.3 \\
\hline
\end{tabular}

The effectiveness of sunscreen was tested using UV-Vis spectrophotometer. Category ability of sunscreen are as follows: (a) At a minimum, with an SPF of 2-4, (b) Currently, the SPF 4-6, (c) Extra, with an SPF of 6-8, (d) maximum SPF 8-15, and (e) Ultra, with SPF > 15. SPF in formula no 3 showed the maximum effect of catechins as antioxidants. This is proven by the highest SPF compared with other formulas. Measurement of SPF from formula with and without cycling test was shown in table 5 and 6 .

Table 5. The SPF value of the formula with cycling test

\begin{tabular}{ccc}
\hline Formula & Concentration $(\mathrm{Ppm})$ & SPF \\
\hline $\mathrm{I}$ & 20 & 1.32 \\
2 & 20 & 6.31 \\
3 & 20 & 12.23 \\
4 & 20 & 6.03 \\
\hline
\end{tabular}

Table 6. The SPF value of the formula without cycling test

\begin{tabular}{ccc}
\hline Formula & Concentration (Ppm) & SPF \\
\hline 1 & 20 & 1.82 \\
2 & 20 & 6.23 \\
3 & 20 & 16.01 \\
4 & 20 & 4.88 \\
\hline
\end{tabular}

\section{CONCLUSION}

Catechins lotion with Formula 3 (catechin concentration of $1 \%)$ provides SPF value of 16 at a concentration of $20 \mathrm{ppm}$, have organoleptic properties are quite stable in color preparations, preparations remain homogeneous and consistent. As for the treatment of accelerated stability test using test Cycling showing the separation and discoloration on the day $1 \mathrm{I}^{\text {th }}$ and $12^{\text {th }}$.

\section{ACKNOWLEDGEMENT}

This work was supported by a grant from Direktorat Riset dan Pengabdian Masyarakat Kementerian Riset Teknologi dan Pendidikan Tinggi Republik Indonesia (Directorate of Research and Community Service Ministry of Research Technology and Higher Education Republic of Indonesia).

\section{REFERENCES}

Aghel, N., Moghimipour, E., Ameri, A. 2007. The characterization of an Anti-Dermatophyte Cream from Zataria Multifora Boiss. Iranian Journal of Pharmaceutical Sciences on Spring. 3(2):77-84.

Isnawati, A., Raini, M., Sampurno, O.D., Mutiatikum, D., Widowati, L., Gitawati, R., 2012. Karakterisasi Tiga Jenis Ekstrak Gambir (Uncaria gambir Roxb) dari Sumatera Barat. Buletin Penelitian Kesehatan. 40(4):20I-208

Lobo, V., Patil, Chandra, N., 2010. Free Radical, Antioxidants and Functional Food: Impact of Human Health. Pharmacognosy Review. 4(8):I 18-126.

Mackiewicz, L., Rimkevicius, A. 2008. Aging Skin. Gerontologija. 9(2): 103-108.

Mansur, J.S., Breeder, M.N., Azulay, R.D. 1986. Determinação do Fator de proteção diesel por espectrofotometria. Anais Brasileiros de Dermalogia, $61: 121-24$

Purwaningsih, S., Salamah, E., Adnin, M.N., 2015. Securities photoprotective Sunscreen Cream with Addition of carrageenan and Black Mangrove fruit (Rhizophora mucronata Lamk.). Journal of Tropical Marine Science and Technology. 7(I): I- 14 .

Sa'adah, L. 2010. Isolation and Identification of Compounds Tannins from Daun Belimbing Wuluh (Averrhoa bilimbi L.). Skripsi. Malang: Department of Chemistry UIN Maulana Malik Ibrahim.

Sayre, R.M., Agin, P.P., Levee, G.J., Madowe, E. 1979. Comparison of In Vivo and In Vitro Testing of Sunscreening Formulas. Photochemistry and Photobiology. 29:559-566. 
Shovyana, H.H., Zulkarnain, A.K. 2013. Physical Stability and Activity of Cream W/O Etanolic Fruit Extract of Mahkota Dewa (Phaleria macrocarpha (Scheff.) Boerl.) As a Sunscreen. Traditional Medicine Journal. I8(2):210-22I.

Silvikasari, Wafa, N.I., Utami, O.Y., Nurhaeni, R., Faris, M. 2010. Uji Efektivitas Katekin Dari Daun Gambir (Uncaria gambir (Hunter) Roxb) Sebagai Bahan Alternatif Pengawet Tahu di Kabupaten Bogor. Skripsi. Bogor: Institut Pertanian Bogor.

Towaha, J. 2010. Catechin in Gambir and its role in Semi industry. Popular Spice and Industrial Plants. I(17).

Winarsi, H. 2007. Natural Antioxidants and Free Radicals. Yogyakarta: Kanisius. 